Article

\title{
Interdecadal Change in the Relationship between Northern and Southern Hemisphere Meridional Circulation over the Western Pacific Ocean
}

\author{
Ya Gao ${ }^{1,2}$, Dong Chen ${ }^{1,2, *}$ and Huijun Wang ${ }^{1,2}$ \\ 1 Nansen-Zhu International Research Centre, Institute of Atmospheric Physics, Chinese Academy of Sciences, \\ Beijing 100029, China; gaoy@mail.iap.ac.cn (Y.G.); wanghj@mail.iap.ac.cn (H.W.) \\ 2 Key Laboratory of Meteorological Disaster/Collaborative Innovation Center on Forecast and Evaluation of \\ Meteorological Disasters, Nanjing University of Information Science and Technology, Nanjing 210044, China \\ * Correspondence: chend@mail.iap.ac.cn
}

Received: 3 September 2020; Accepted: 11 October 2020; Published: 16 October 2020

\begin{abstract}
The western North Pacific monsoon in the Northern Hemisphere $(\mathrm{NH})$ and the local Hadley circulation in the Southern Hemisphere (SH) are important components of the vertical meridional circulation over the western Pacific Ocean. Here, we define the SH meridional circulation (SHMC) and $\mathrm{NH}$ meridional circulation (NHMC) and investigate their relationship over the western Pacific Ocean. Although they are consistent integrally in the climatological circulation, the NHMC and SHMC do not have a positive change relationship but a significantly negative relationship. In addition, this negative correlation experiences an interdecadal change, with one closely related period during 1989-2003 (Period 2, P2) and two weakened related periods during 1979-1988 (Period 1, P1) and 2004-2017 (Period 3, P3). Through the analysis of the meridional wind field at lower and upper levels, we found that the SHMC moves northward during P2, which can result in a close relationship with the NHMC. The possible mechanism is as follows: The Walker circulation strengthened in P2, which strengthened the ascending motion over the western Pacific Ocean, thus inducing the SHMC to strengthen and move northward, resulting in a significantly stronger relationship with the NHMC.
\end{abstract}

Keywords: meridional circulation; western Pacific Ocean; central-eastern Pacific SST; interdecadal change

\section{Introduction}

The tropical western Pacific region is a climatic region where the air-sea interaction is strong and multiple circulations influence each other. The region encompasses several important monsoon systems, such as the East Asian monsoon, the northwest Pacific monsoon, and the South China Sea monsoon, as well as the subtropical high, cross-equatorial airflow, and other sub-monsoon systems (Figure 1). In addition, the meridional Hadley circulation and the zonal Walker circulation and anti-Walker circulation converge here. Because of its particularity, this region plays a crucial role in the interaction and energy exchange between the Northern Hemisphere $(\mathrm{NH})$ and Southern Hemisphere (SH) and in the important water vapor channel.

Therefore, previous studies have paid much attention to this area. The tropical western Pacific Ocean has an important influence on East Asian summer systems [1-4] and also plays a crucial role in the El Niño Southern Oscillation (ENSO) cycle in the tropical Pacific [5-9], which can build a relationship with the ENSO through equatorial zonal wind anomalies and Rossby wave, and influence the East Asian climate through tropical convective activities and North Western Pacific subtropical high, and so on. Thus, the tropical western Pacific Ocean is a key region connecting the north and south directions (such as the Northern and Southern Hemisphere meridional circulations) and the east and west directions (e.g., the Walker circulation). Since the tropical western Pacific comprises the ascending branch of the 
Walker circulation, the tropical Pacific ENSO cycle also affects large-scale circulation and convective activity over the western Pacific Ocean and the East Asian summer monsoon circulation [10-15].

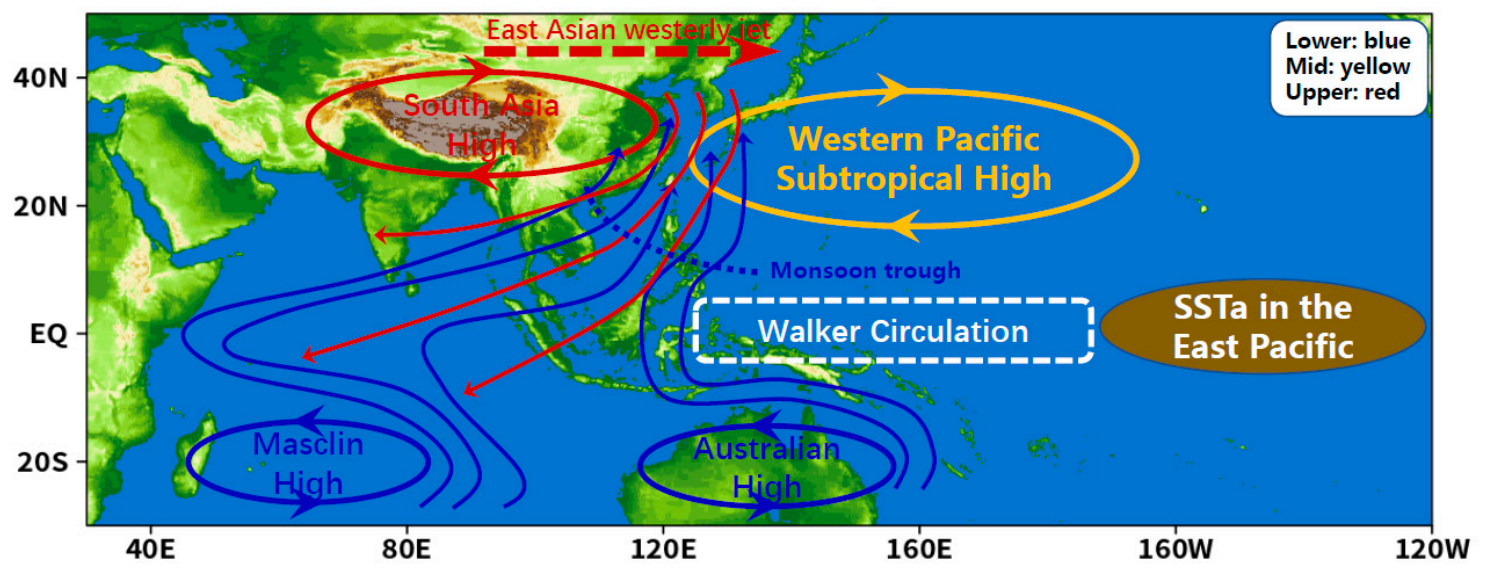

Figure 1. The schematic diagram of monsoon systems.

As one of the major large-scale circulations in the low-latitude atmosphere, the Hadley circulation has a close relationship with the $\mathrm{NH}$ and SH climate system. Many previous studies have investigated the changes in the intensity and position of the global Hadley circulation and have found that the Hadley circulation has tended to strengthen and expand poleward in recent years [16-20]. Zhou and Wang [21] considered the Hadley circulation from a seasonal perspective and showed that the Hadley circulation in the NH had an obvious strengthening trend in winter, while it had no obvious linear trend in summer in the SH, mainly showing an interdecadal oscillation pattern of strong, weak, and strong. Sun [22] divided the Hadley circulation into northern and southern components and found that the changes in Hadley circulation in the NH and SH were not consistent. The results showed a stable strengthening trend in the SH but a multidecadal oscillation in the NH. These changes in the large-scale Hadley circulation have a significant effect on circulation and precipitation in the East Asia-northwest Pacific region. For example, the strength of the Hadley circulation anomaly in spring can influence the frequency of local tropical cyclones by affecting the vertical and horizontal variations in summer zonal winds in the northwest Pacific region [23] and can also influence the East Asian summer monsoon and its related subsystems, modulating the distribution of summer precipitation in China [24]. The above studies mainly focus on the global Hadley circulation, but its variation characteristics in different regions are still distinct $[25,26]$. Chen et al. [25] divided the Hadley Circulation into six regions with different performances of the intensity trend and poleward. Owing to the different underlying surfaces, the zonally Hadley circulation exhibits regional variability, which requires a specific analysis of each region. Huang [26] studied the long-term trend of the boreal spring Hadley circulation intensity over the western Pacific Ocean. Regional Hadley circulation can significantly influence regional climate change [27-31]. For example, the decreasing trends in west African rainfall, summer rainfall in northern China, and snow accumulation over the southern Himalayas are all closely related to the regional Hadley and Walker circulations [28]. Zeng et al. [29] found that the zonal Walker circulation and Hadley cell over the Pacific Ocean were linked to the anomalous East Asian winter monsoon.

Previous studies have paid more attention to the overall change characteristics of the global Hadley circulation but have paid less attention to whether the north and south parts of the Hadley circulation changed uniformly. Moreover, studies on the features and impacts of regional Hadley circulation, especially its interdecadal aspects, are still unclear. Previous studies have shown that the strengthened meridional circulation in the $\mathrm{SH}$ could induce strong cross-equatorial flow, thus influencing the establishment and development of the East Asian summer monsoon [32,33]. Therefore, are the changes in $\mathrm{NH}$ and SH meridional circulation consistent? When the meridional circulation is stronger (weaker) in the $\mathrm{SH}$, is the meridional circulation stronger (weaker) in the NH? Is there a long-term stable 
relationship between these two circulations? What factors modulate this relationship? This paper focuses on the relationship and interaction between the $\mathrm{NH}$ and $\mathrm{SH}$ meridional circulations in the western Pacific region.

The paper is organized as follows: The data and methods are described in Section 2; the main results, including the relationship between the $\mathrm{NH}$ meridional circulation index (NHMCI) and $\mathrm{SH}$ meridional circulation index (SHMCI), the reason for the relationship between the NHMC and SHMC occurring at an interdecadal scale, and the possible mechanism behind this modulating process, are presented in Section 3, Section 4 andSection 5; and, in Section 6, we present the conclusions and discussion.

\section{Datasets and Methods}

The observational datasets used in the current study include the Global Precipitation Climatology Project (GPCP) version 2.3 monthly precipitation analysis [34] with a horizontal resolution of $2.5^{\circ}$ latitude by $2.5^{\circ}$ longitude, the National Centers for Environmental Prediction/Department of Energy (NCEP/DOE) monthly reanalysis 2 dataset [35] with a horizontal resolution of $2.5^{\circ}$ latitude by $2.5^{\circ}$ longitude, the National Centers for Environmental Prediction/National Center for Atmospheric Research (NCEP/NCAR) monthly reanalysis dataset [36] with a horizontal resolution of $2.5^{\circ}$ latitude by $2.5^{\circ}$ longitude, the ERA5 monthly reanalysis dataset with a horizontal resolution of $0.25^{\circ}$ latitude by $0.25^{\circ}$ longitude [37], the ERA-interim monthly reanalysis dataset with a horizontal resolution of $1^{\circ}$ latitude by $1^{\circ}$ longitude [37], and the National Oceanic and Atmospheric Administration (NOAA) monthly extended reconstructed sea surface temperature (ERSST, version 3b) [38] dataset with a horizontal resolution of $2^{\circ}$ latitude by $2^{\circ}$ longitude. In this study, summer is defined as the seasonal mean from June to September (JJAS) in the period 1979-2017.

The NHMCI is defined as the regionally averaged $\left(120^{\circ} \mathrm{E}-155^{\circ} \mathrm{E}, 20^{\circ} \mathrm{N}-30^{\circ} \mathrm{N}\right)$ meridional wind shear between 850 and $200 \mathrm{hPa}$. The SHMCI is defined as the regionally averaged $\left(120^{\circ} \mathrm{E}-155^{\circ} \mathrm{E}\right.$, $10^{\circ} \mathrm{S}-0^{\circ}$ ) meridional wind shear between 850 and $200 \mathrm{hPa}$ (Figure 1). The Niño3.4 index is defined as the regionally averaged SST anomaly (SSTA) in the central-eastern Pacific Ocean $\left(5^{\circ} \mathrm{S}-5^{\circ} \mathrm{N}, 170^{\circ} \mathrm{W}-120^{\circ} \mathrm{W}\right)$.

The methods used in the article are an 11-year sliding correlation, linear regression analysis. A two-tailed Student's t-test is used for the statistical significance test of correlation coefficients and differences between two fields.

\section{Climatology of the Atmospheric Circulations over the Western Pacific Ocean}

At both 850 and $200 \mathrm{hPa}$, there are two large meridional wind regions, with southerly winds at lower levels and northerly winds at upper levels, which are located in tropical areas of the $\mathrm{NH}$ $\left(120^{\circ} \mathrm{E}-155^{\circ} \mathrm{E}, 20^{\circ} \mathrm{N}-30^{\circ} \mathrm{N}\right)$ and $\mathrm{SH}\left(120^{\circ} \mathrm{E}-155^{\circ} \mathrm{E}, 10^{\circ} \mathrm{S}-0^{\circ}\right)$ over the western Pacific Ocean (Figure 2, red boxes regions). To analyze the complete characteristics of the north and south circulations, we give the climatology of the zonally averaged vertical meridional circulation field over the western Pacific Ocean (Figure 3a). The meridional circulation over the western Pacific Ocean presents an integral consistent feature with the ascending (descending) branch north (south) of $5^{\circ} \mathrm{S}$, southerlies at lower levels, and northerlies at upper levels. Although it has a consistent feature in the climatological circulation, there are two systems, i.e., the western North Pacific monsoon superimposed on the local Hadley circulation in the $\mathrm{NH}$ and the local Hadley circulation in the SH.

To investigate the relationship between the two meridional circulations in the Northern and Southern Hemispheres, we defined the NHMCI and SHMCI, and the areal extent is selected by the location of the maximum meridional wind given in Figure 2. The regression streamlines show that the NHMC and SHMC do not have a positive change relationship but a significantly negative relationship (Figure $3 b, c)$. This indicates that when the NHMC is strengthened (weakened), the SHMC is weakened (strengthened). Furthermore, we analyze the sliding correlation between these two meridional circulations with an 11-year window (Figure 4). The negative relationship between the $\mathrm{NHMCI}$ and SHMCI is unstable, with a significant interdecadal change characteristic and a strong 
linkage during 1989-2003. At other periods, the negative correlation between these two circulation indices is weak. To confirm this interdecadal change of this relationship, we also used NCEP/NCAR reanalysis data, ERA5, and ERA-interim data. All these data are interpolated to the $2.5^{\circ}$ resolutions. The results of the NCEP/NCAR and NCEP/DOE are consistent. In addition, the ERA5 and ERA-interim results also show this similar interdecadal change (Figure omitted), but there are some small differences between the two datasets at the time of decadal change. Considering the consistency of the data and the comparison with the previous work, hereafter, we mainly use NCEP/DOE reanalysis data to study the research.
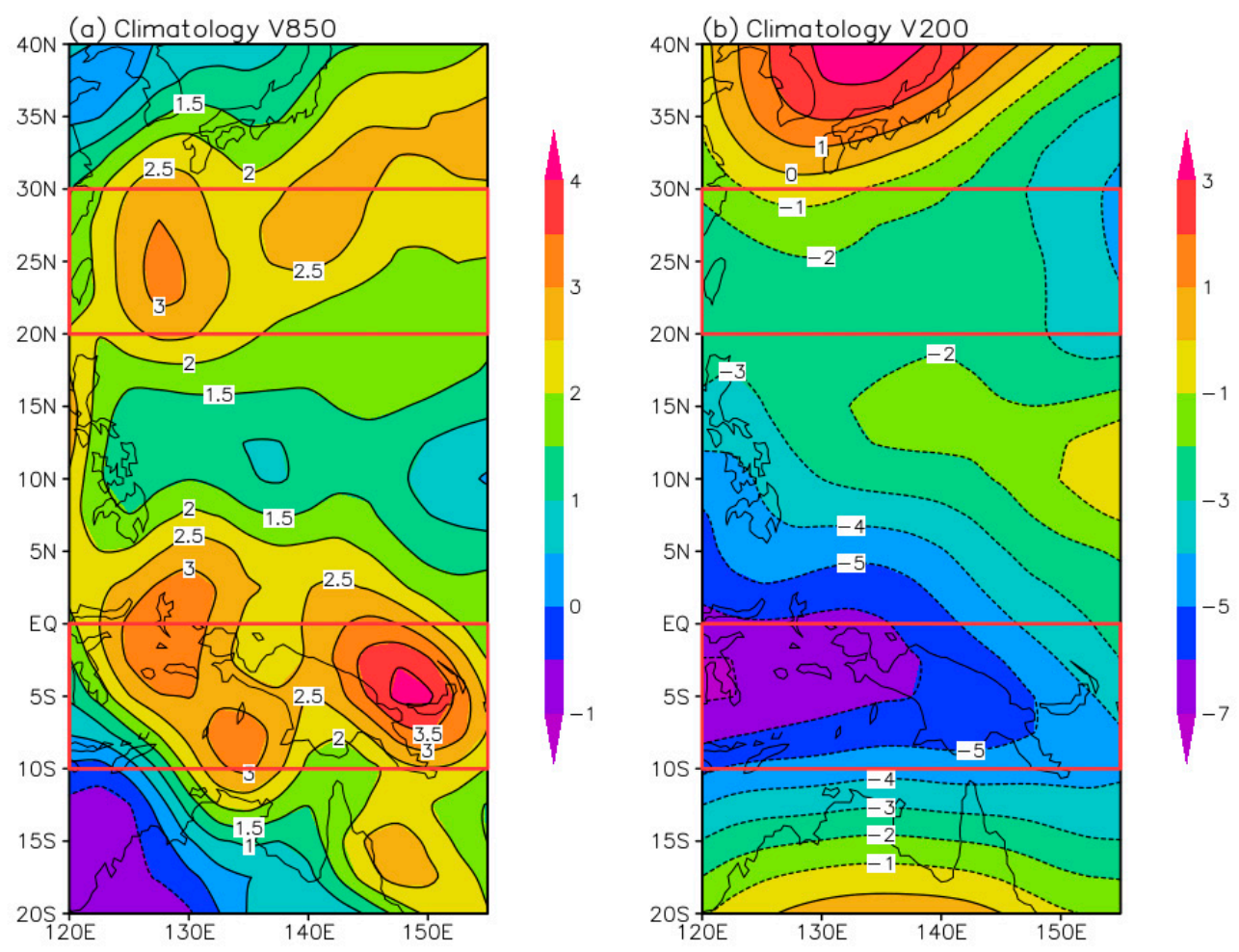

Figure 2. Climatology of meridional wind at (a) $850 \mathrm{hPa}$ and (b) $200 \mathrm{hPa}$ during summer (June-September, JJAS) from 1979 to 2017 (unit m/s). The red boxes are the maximum meridional wind regions, which are used to define the meridional circulation indices in Northern and Southern Hemisphere.
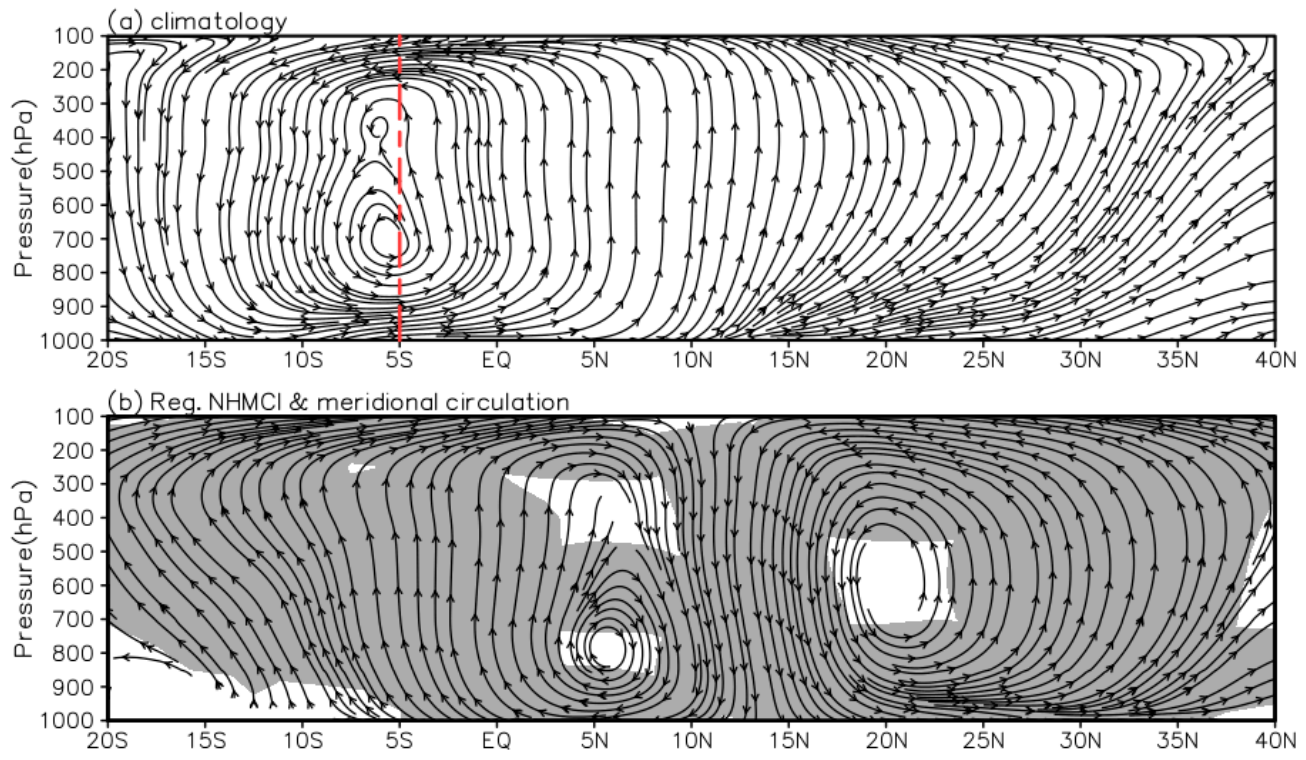

Figure 3. Cont. 


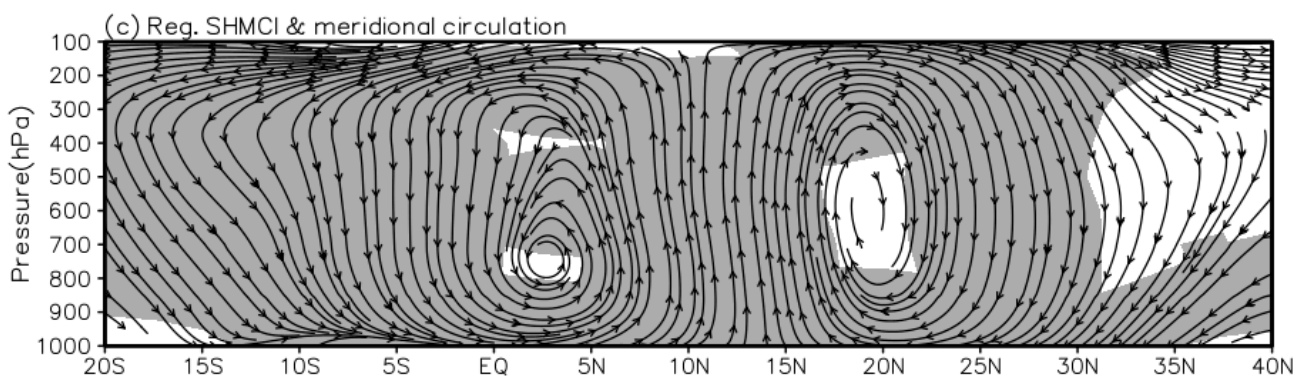

Figure 3. (a) Climatology of the zonally averaged $\left(120^{\circ} \mathrm{E}-155^{\circ} \mathrm{E}\right)$ vertical meridional circulation during 1979-2017 in a latitude-height cross-section, the red line represents the approximate boundary between the ascending branch and descending branch; (b) The streamlines show the linear regression map between the Northern Hemisphere meridional circulation index (NHMCI) and the summer zonally averaged $\left(120^{\circ} \mathrm{E}-155^{\circ} \mathrm{E}\right)$ vertical meridional circulation; (c) The same as (b) except it is for the Southern Hemisphere meridional circulation index (SHMCI). The shaded regions represent the anomalous meridional wind and vertical wind significant at the $95 \%$ confidence level. The vertical velocity has been multiplied by -100 .

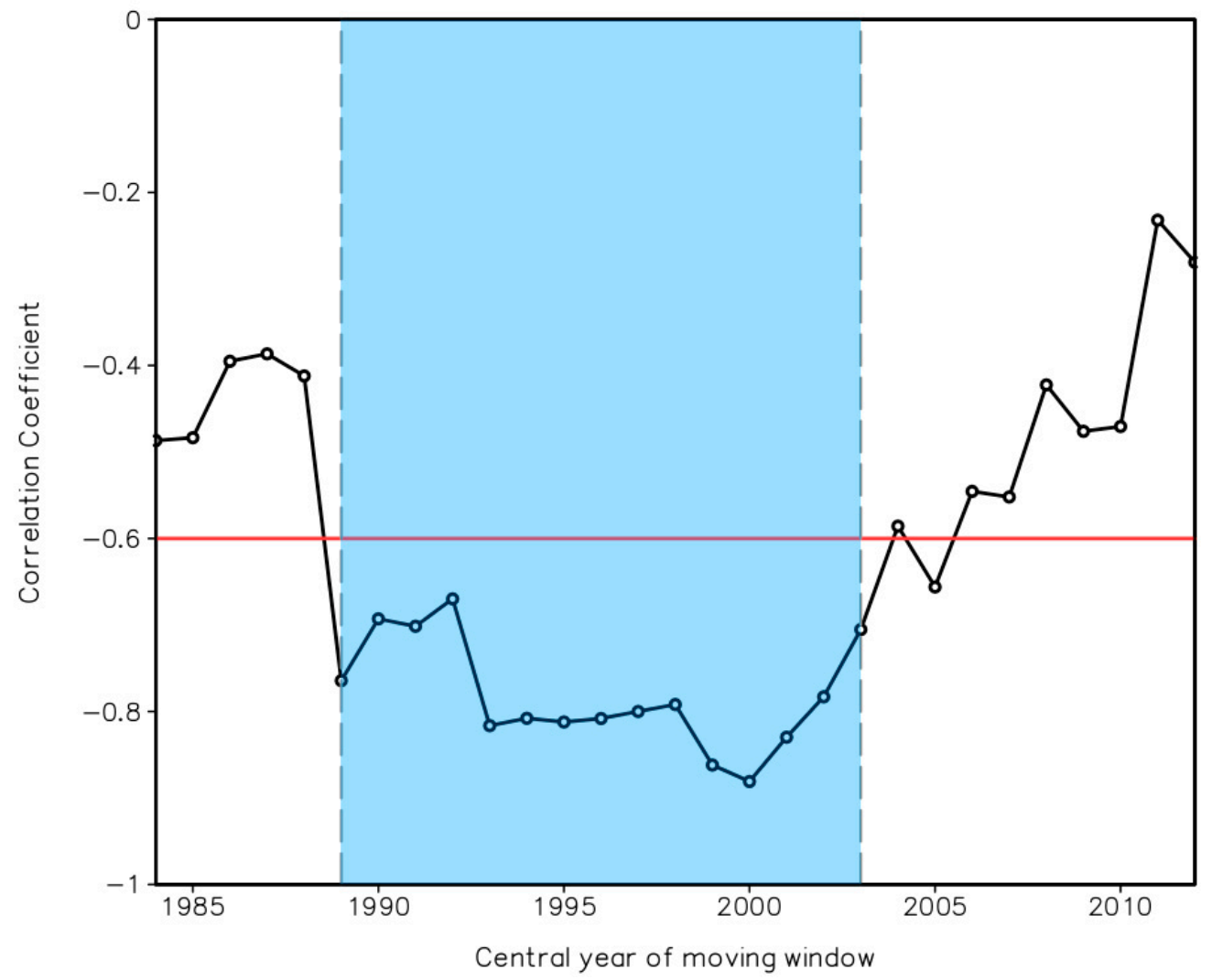

Figure 4. Eleven-year sliding correlation of the NHMCI and SHMCI during 1979-2017, where the red horizontal line denotes the $95 \%$ confidence level for the correlation coefficient. The blue region denotes the correlation coefficients between NHMCI and SHMCI are significant at 95\% confidence level.

\section{Interdecadal Change of the Relationship between the NHMC and SHMC}

To detect the reason why the relationship between the NHMC and SHMC has experienced an interdecadal change, we divide 1979-2017 into three periods, i.e., one closely related period during 1989-2003 (Period 2, P2) and two weakened related periods during 1979-1988 (Period 1, P1) and 2004-2017 (Period 3, P3). At $850 \mathrm{hPa}$, the meridional wind is southerly with a maximum wind speed over $20^{\circ} \mathrm{N}-30^{\circ} \mathrm{N}$ and $10^{\circ} \mathrm{S}-0^{\circ}$ (Figure 2a). The difference between $\mathrm{P} 2$ and $\mathrm{P} 1$ shows an anomalous northerly wind over $10^{\circ} \mathrm{S}-0^{\circ}$ and an anomalous southerly wind over $0^{\circ}-10^{\circ} \mathrm{N}$ (Figure $5 \mathrm{a}, \mathrm{c}$ ). This illustrates that 
the lower-level meridional wind of the SHMC moves northward during P2. The situation is remarkable in P2-P3, which shows a strong anomalous southerly wind over the $0^{\circ}-10^{\circ} \mathrm{N}$ area (Figure $5 \mathrm{~b}$ ). Figure $5 \mathrm{c}$ represents the location of the maximum anomalous southerly of the SHMC at approximately $5^{\circ} \mathrm{N}$ (Green line), which indicates that, as compared with P1, the meridional wind of the SHMC at $850 \mathrm{hPa}$ moves northward in P2. Figure $5 \mathrm{~d}$ is the same as Figure 5c except it represents P3 and the difference between P3 and P2. Compared to P3, the meridional wind is more obviously moving northward in P2.
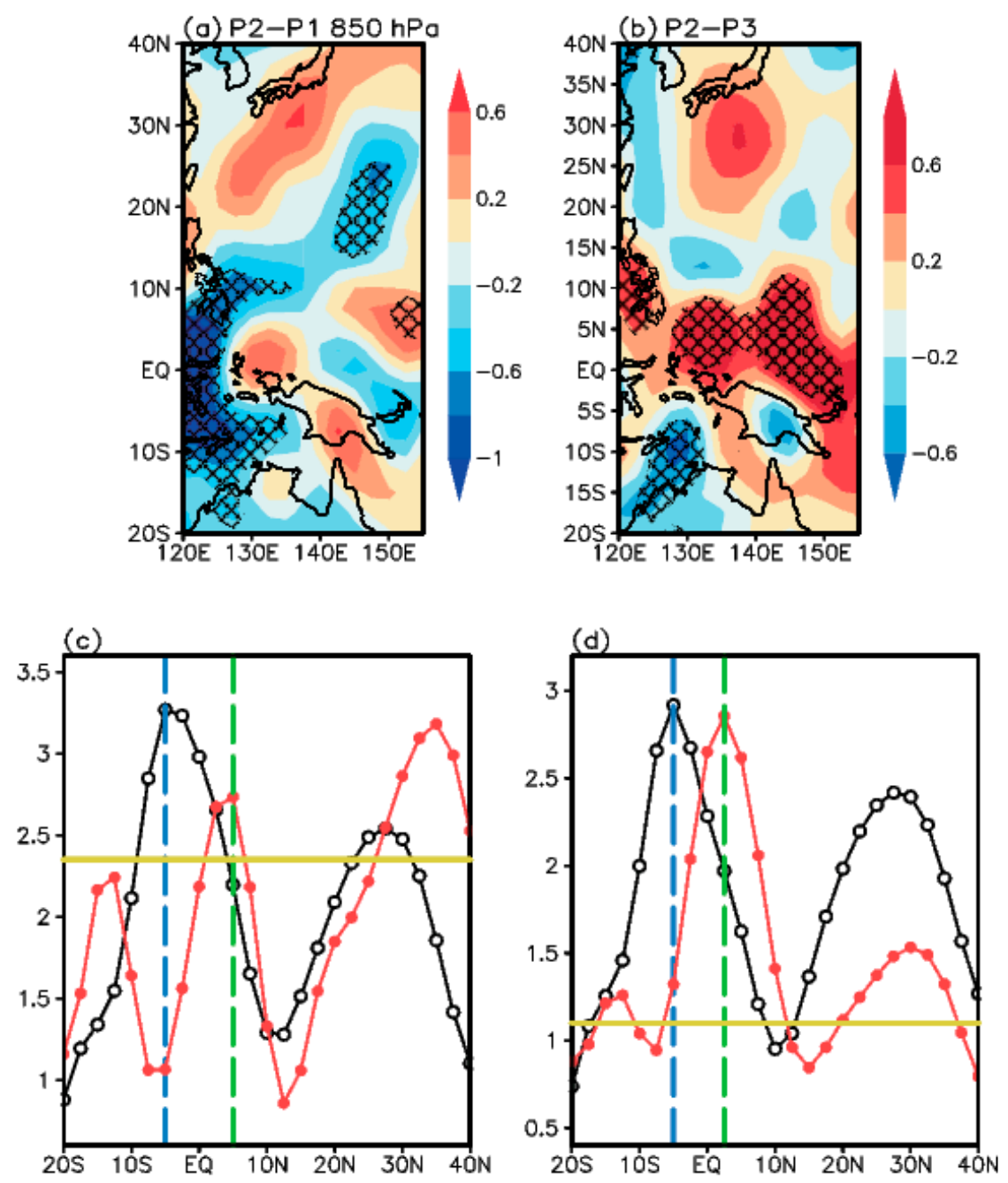

Figure 5. The differences in meridional wind at $850 \mathrm{hPa}$ between (a) Period 2 (P2, 1989-2003) and Period 1 (P1, 1979-1988) and between (b) P2 (1989-2003) and Period 3 (P3, 2004-2017), where the gridded regions represent the anomalous meridional wind significant at the $95 \%$ confidence level (unit $\mathrm{m} / \mathrm{s}$ ); (c) The black line denotes the zonally averaged $\left(125^{\circ} \mathrm{E}-55^{\circ} \mathrm{E}\right)$ meridional wind at $850 \mathrm{hPa}$ during P1 (left ordinate is the magnitude of the wind speed, unit $\mathrm{m} / \mathrm{s}$ ), the red line denotes the difference in the zonally averaged $\left(125^{\circ} \mathrm{E}-155^{\circ} \mathrm{E}\right)$ meridional wind at $850 \mathrm{hPa}$ between P2 and P1 (P2-P1) (right ordinate is the magnitude of the wind speed, unit m/s); (d) The same as (c), except, the black line is for P3 (left ordinate is the magnitude of the wind speed, unit $\mathrm{m} / \mathrm{s}$ ), and the red line is for the difference between P2 and P3 (P2-P3) (right ordinate is the magnitude of the wind speed, unit m/s).

Figure 6 is the same as Figure 5, except it represents the change in upper-level features. In Figure 6a, the northerlies are weakened in the SHMC over $10^{\circ} \mathrm{S}-0^{\circ}$, while the northerlies are strengthened over the $0^{\circ}-10^{\circ} \mathrm{N}$ area. The difference between P3 and P2 at $200 \mathrm{hPa}$ is remarkable which shows the northerly strengthened over the $5^{\circ} \mathrm{S}-10^{\circ} \mathrm{N}$ area (Figure $6 \mathrm{~b}$ ). The results in Figure $6 \mathrm{c}, \mathrm{d}$ are the same as 
the results in Figure 5c,d. Compared with P1 and P3, the northerly wind associated with SHMC moves north during P2.
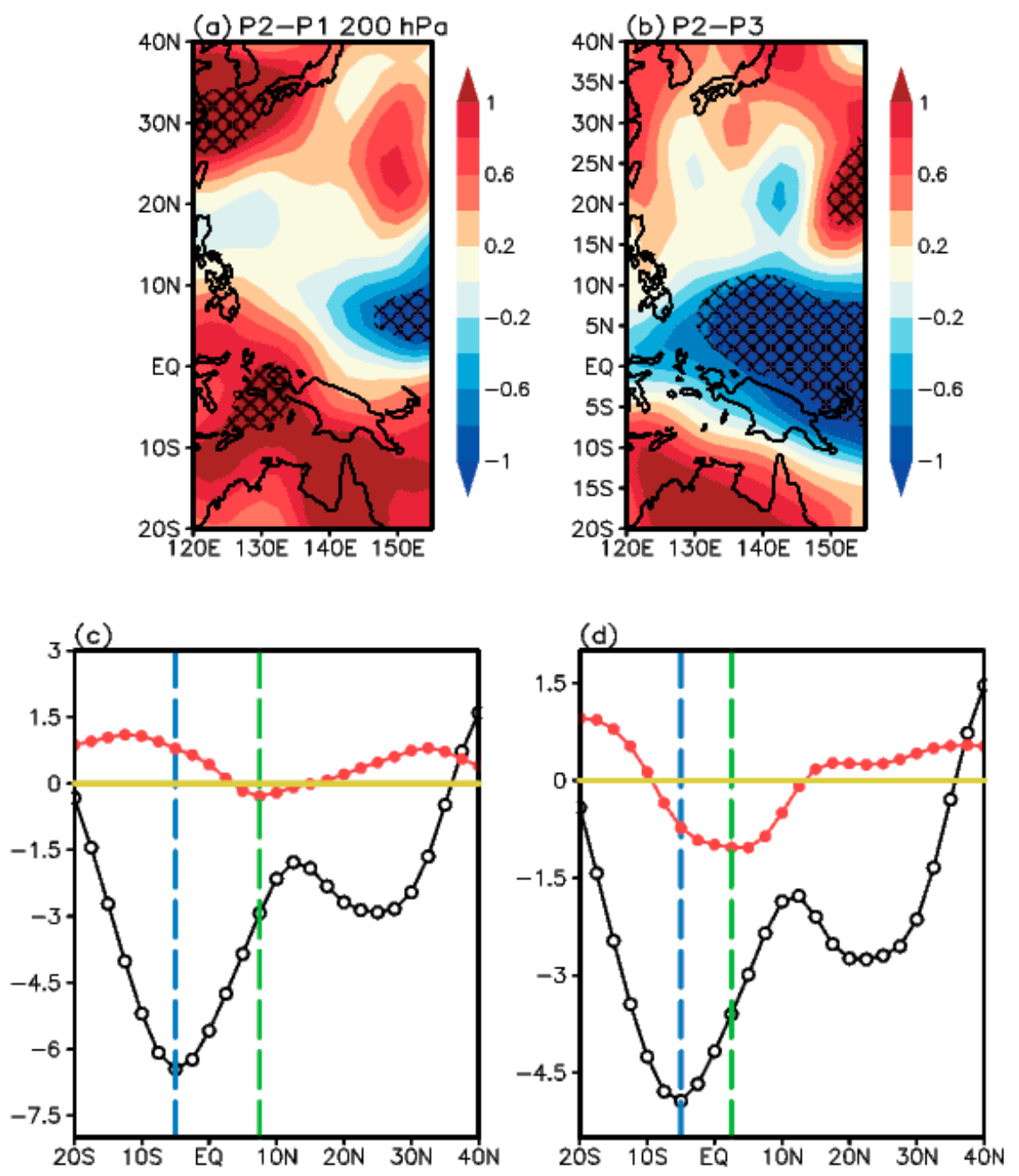

Figure 6. The differences in meridional wind at $200 \mathrm{hPa}$ between (a) Period 2 (P2, 1989-2003) and Period 1 (P1, 1979-1988) and between (b) P2 (1989-2003) and Period 3 (P3, 2004-2017), where the gridded regions represent the anomalous meridional wind significant at the $95 \%$ confidence level (unit $\mathrm{m} / \mathrm{s}$ ); (c) The black line denotes the zonally averaged $\left(125^{\circ} \mathrm{E}-55^{\circ} \mathrm{E}\right)$ meridional wind at $200 \mathrm{hPa}$ during P1 (left ordinate is the magnitude of the wind speed, unit $\mathrm{m} / \mathrm{s}$ ), the red line denotes the difference in the zonally averaged $\left(125^{\circ} \mathrm{E}-155^{\circ} \mathrm{E}\right)$ meridional wind at $200 \mathrm{hPa}$ between P2 and P1 (P2-P1) (right ordinate is the magnitude of the wind speed, unit m/s); (d) The same as (c), except, the black line is for P3 (left ordinate is the magnitude of the wind speed, unit $\mathrm{m} / \mathrm{s}$ ), and the red line is for the difference between P2 and P3 (P2-P3) (right ordinate is the magnitude of the wind speed, unit m/s).

The meridional wind shear between 850 and $200 \mathrm{hPa}$, during 1979-2019, is given below in Figure 7a, which shows that the maximum speed of the SHMC is located over $10^{\circ} \mathrm{S}-10^{\circ} \mathrm{N}$. Thus, to analyze the location change in the SHMC, we give the location of the maximum meridional wind at $850 \mathrm{hPa}$ (black line) and the location of the maximum vertical meridional wind shear between 850 and $200 \mathrm{hPa}$ (yellow line) from $10^{\circ} \mathrm{S}-10^{\circ} \mathrm{N}$ (Figure $7 \mathrm{~b}$ ). The wind at $850 \mathrm{hPa}$ and the vertical wind shear between $850 \mathrm{hPa}$ and $200 \mathrm{hPa}$ both show that the maximum meridional wind of the SHMC moves northward during P2. 

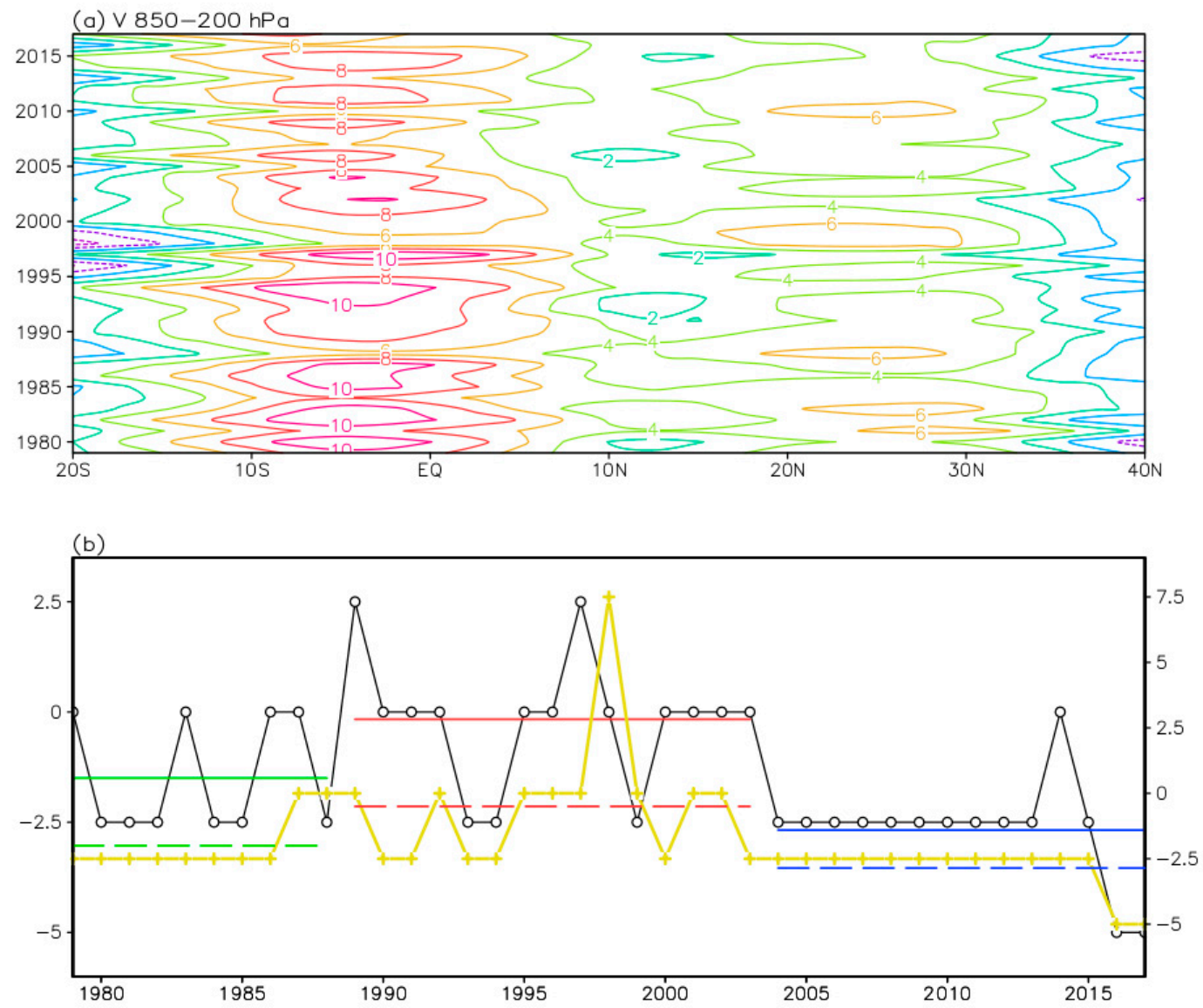

Figure 7. (a) Zonally averaged $\left(125^{\circ} \mathrm{E}-155^{\circ} \mathrm{E}\right)$ vertical meridional wind shear between 850 and $200 \mathrm{hPa}$ during 1979-2019 (unit $\mathrm{m} / \mathrm{s}$ ); (b) The black line represents the location of the maximum meridional wind at $850 \mathrm{hPa}$ from $10^{\circ} \mathrm{S}-10^{\circ} \mathrm{N}$ (left ordinate denotes latitude, unit ${ }^{\circ}$ ), the yellow line represents the location of maximum vertical meridional wind shear between 850 and $200 \mathrm{hPa}$ ranging from $10^{\circ} \mathrm{S}-10^{\circ} \mathrm{N}$ (right ordinate denotes latitude, unit ${ }^{\circ}$ ). The green line represents the average location of the maximum meridional wind at $850 \mathrm{hPa}$ and maximum vertical meridional wind shear between 850 and $200 \mathrm{hPa}$ during P1; red and blue lines are the same as the green line, but they represent P2 and $\mathrm{P} 3$, respectively.

\section{Possible Mechanisms}

On the basis of the average meridional wind at the lower and upper levels and the maximum meridional wind speed of the SHMC, owing to the SHMC and the NHMC share the ascending branch of the tropical western Pacific, the SHMC moving northward in P2 can lead to their relationship significantly strengthened and present a strong negative correlation during P2. By analyzing the SST distribution corresponding to the NHMC and SHMC, we found that during P2, the relationship between NHMCI and SST anomaly is significantly enhanced. When the NHMCI is strengthened, the corresponding SST field shows a La Niña-like pattern, with anomalously warm SSTs near the Maritime Continent and anomalously cold SSTs in the central-eastern Pacific Ocean (Figure 8a). The relationship between SHMCI and SST anomaly is opposite to the NHMCI's. When the SHMCI is strengthened, the corresponding SST field shows an El Niño-like pattern, with anomalously cold SSTs near the Maritime Continent and anomalously warm SSTs in the central-eastern Pacific Ocean (Figure 8b). Both the linkages between the NHMCI and tropical Pacific SST, and SHMCI and tropical Pacific SST are remarkable during P2. However, during P1 and P3, the relative NHMCI SST patterns show that the anomalously warm SSTs over the Maritime Continent are not significant, and the relationship of the NHMCI with a La Niña-like distribution is unstable (Figure 8c,e). However, the correlations are stable between the SHMCI and SST during P1 and P3 (Figure 8d,f), although the 
relationships of the SHMCI with SST are weaker than that in P2 over the Maritime Continent and central-eastern Pacific Ocean.
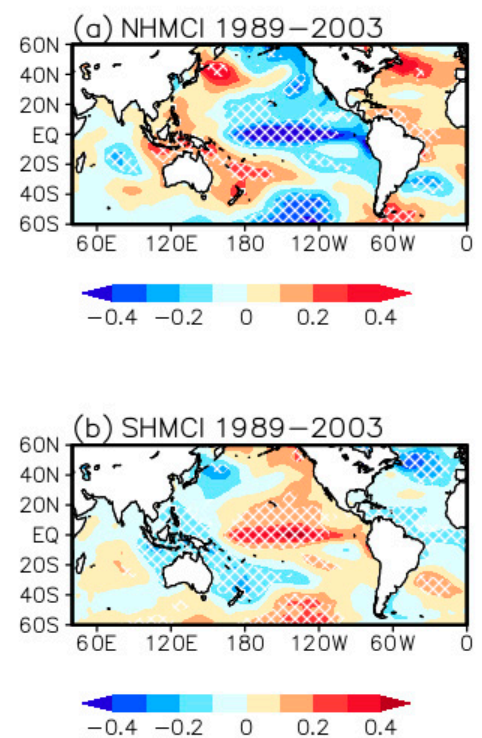
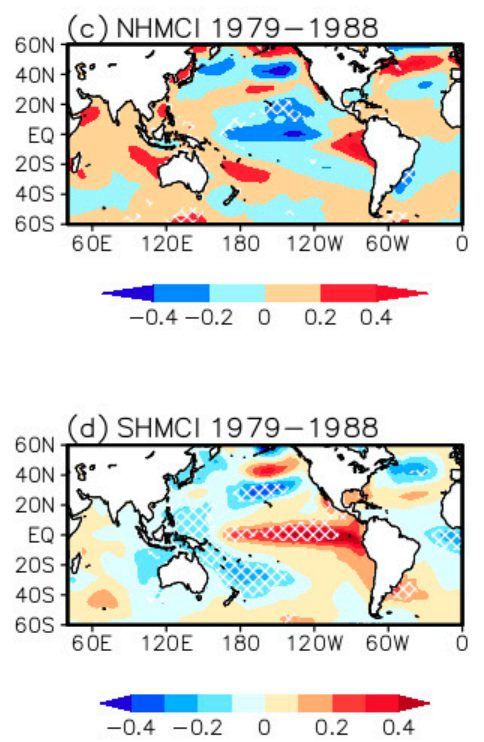
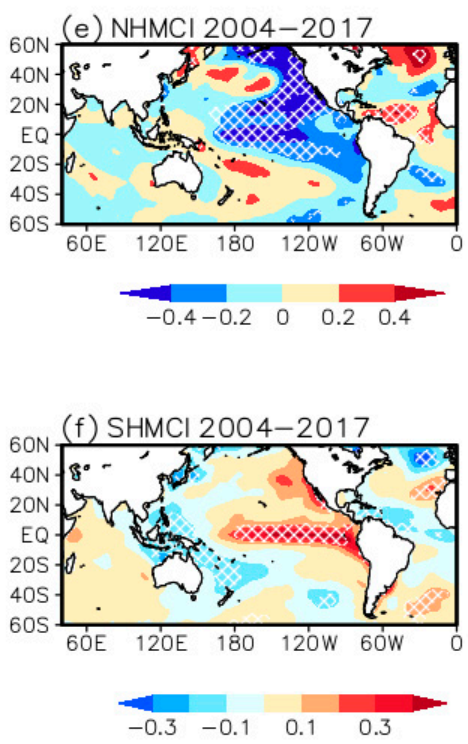

Figure 8. Linear regression maps of the NHMCI and SHMCI with the summer SST field during (a,b) 1989-2004; (c,d) 1979-1988; and (e,f) 2004-2017 (unit ${ }^{\circ} \mathrm{C}$ ). The gridded regions represent the correlations that are positively and negatively significant at the $95 \%$ confidence level.

Furthermore, the relationships between the Niño3.4 index and $500 \mathrm{hPa}$ vertical velocity in these three periods is calculated (Figure 9). In P2, the Niño3.4 index shows a strong relationship with the $500 \mathrm{hPa}$ vertical velocity over the western Pacific Ocean but a weak relationship in the central-eastern Pacific Ocean in the meridional direction. However, the opposite is true for P1 and P3, which have a strong relationship with the $500 \mathrm{hPa}$ vertical velocity over the central-eastern Pacific Ocean and a weak relationship over the western Pacific Ocean in the meridional direction. This means that in P2 period, the SSTA in the tropical central-eastern Pacific Ocean mainly leads to the change of vertical velocity over the western Pacific, while in P1 and P3, the main change region of vertical velocity corresponding to the SSTA is over the eastern Pacific. This conclusion can be further confirmed by the relationship between the Niño3.4 index and zonally averaged vertical velocity, which has significantly strengthened over the western Pacific region in P2, while the relationships are relatively weaker in P1 and P3 (Figure 10a,c,e). However, this relationship between the Niño3.4 index and the zonally averaged vertical field of vertical velocity over the eastern Pacific Ocean is weaker in P2 and stronger in P1 and P3 (Figure 10b,d,f). The sliding correlation also illustrates that the correlation between the Niño3.4 index and vertical velocity over the western Pacific region is strengthened in P2 (Figure 11a). Figure $11 b, c$ shows the differences in vertical velocity between P2 (P3) and P1, both of them show that in P2, the vertical velocity of the ascending motion is weakened in the south part, but enhanced in the north part, as compare with $\mathrm{P} 1$ and $\mathrm{P} 3$, which indicates that the vertical ascending branch of the meridional circulation moved northward and strengthened during P2.

Therefore, the relationship of SSTs between the central-eastern Pacific and western Pacific is significant during the entire period. Due to the ascending branch of the SHMC located in the Maritime Continent, correlations are stable between the SHMCI and SST over central-eastern Pacific during these three periods. However, the relationship between the Niño3.4 index and the tropical western Pacific circulation has an interdecadal oscillation. When the zonal linkage is strengthened over the tropical Pacific Ocean in P2, the linkage of the central-eastern Pacific SST and Maritime Continent SST is strengthened, which can enhance the vertical motion over the western Pacific, making the ascending motion of the SHMC strengthened and SHMC moving northward. Thus, the northward ascending branch of SHMC moves close to the ascending branch of NHMC, both the NHMC and SHMC can share 
one ascending motion, making the relationship between NHMC and SHMC more intimate. However, in P1 and P3, the local meridional circulation is strengthened over the tropical central-eastern Pacific Ocean, while zonal circulation is weakened. Thus, when the eastern Pacific SST has less impact on the Maritime Continent convective activities, the ascending motion over the western Pacific Ocean is weaker than P2, which inducing the linkage between NHMC and SHMC is weakened.
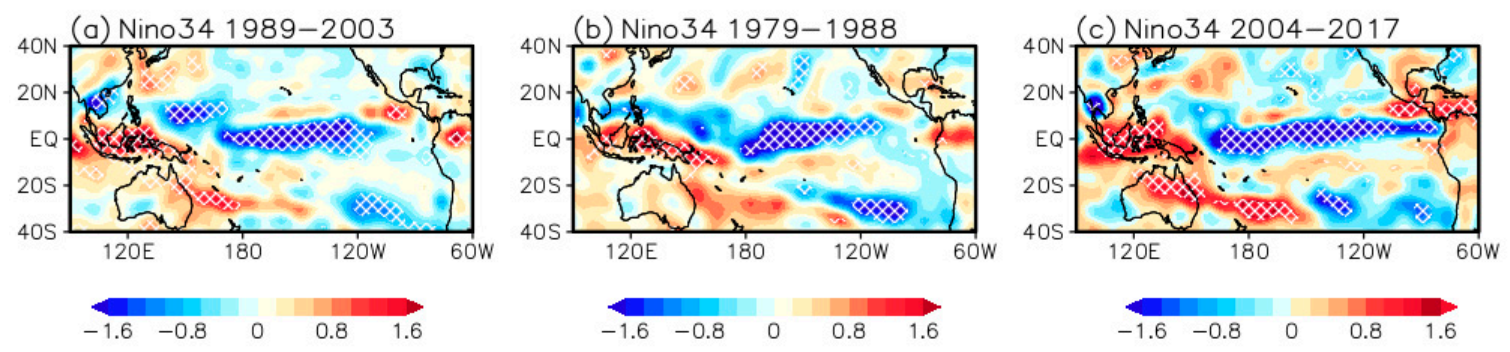

Figure 9. Linear regression maps of the Niño3.4 index with the summer vertical velocity field (omega) at $500 \mathrm{hPa}$ during (a) 1989-2003; (b) 1979-1988; and (c) 2004-2017 (unit P/s); the vertical velocity has been multiplied by 100 . The gridded regions represent the correlations that are positively and negatively significant at the $95 \%$ confidence level.
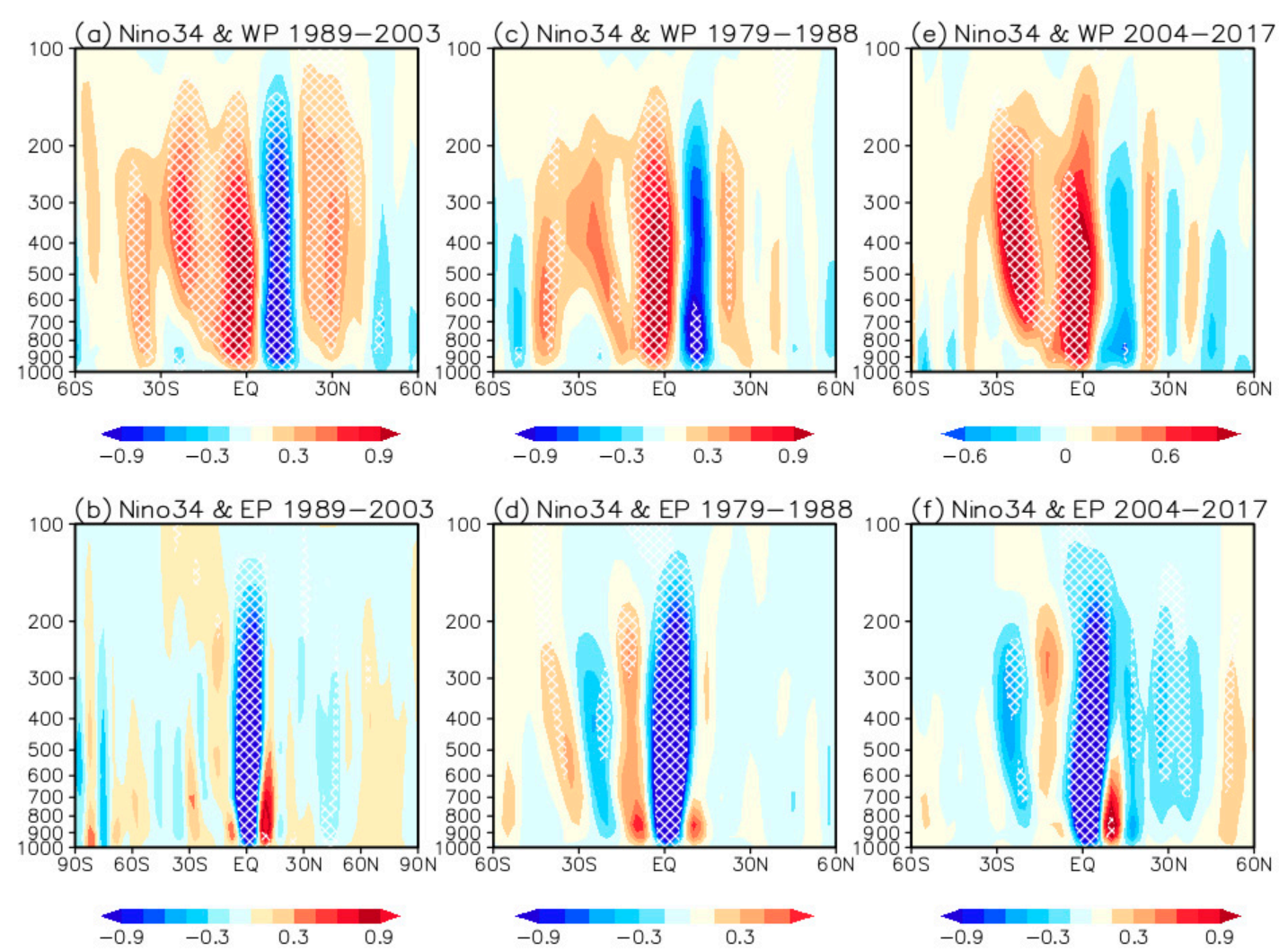

Figure 10. Linear regression maps of the Niño3.4 index with the zonally averaged $\left(120^{\circ} \mathrm{E}-155^{\circ} \mathrm{E}\right)$ vertical field of the summer vertical velocity (omega) in the western Pacific region during (a) 1989-2003; (c) 1979-1988; and (e) 2004-2017. (b,d,f) same as (a,c,e) but for the zonally averaged $\left(180^{\circ}-100^{\circ} \mathrm{W}\right)$ vertical summer omega field in the eastern Pacific region (unit $\mathrm{P} / \mathrm{s}$ ); the vertical velocity has been multiplied by 100 . The gridded regions indicate that the correlations are positively and negatively significant at the $95 \%$ confidence level. 

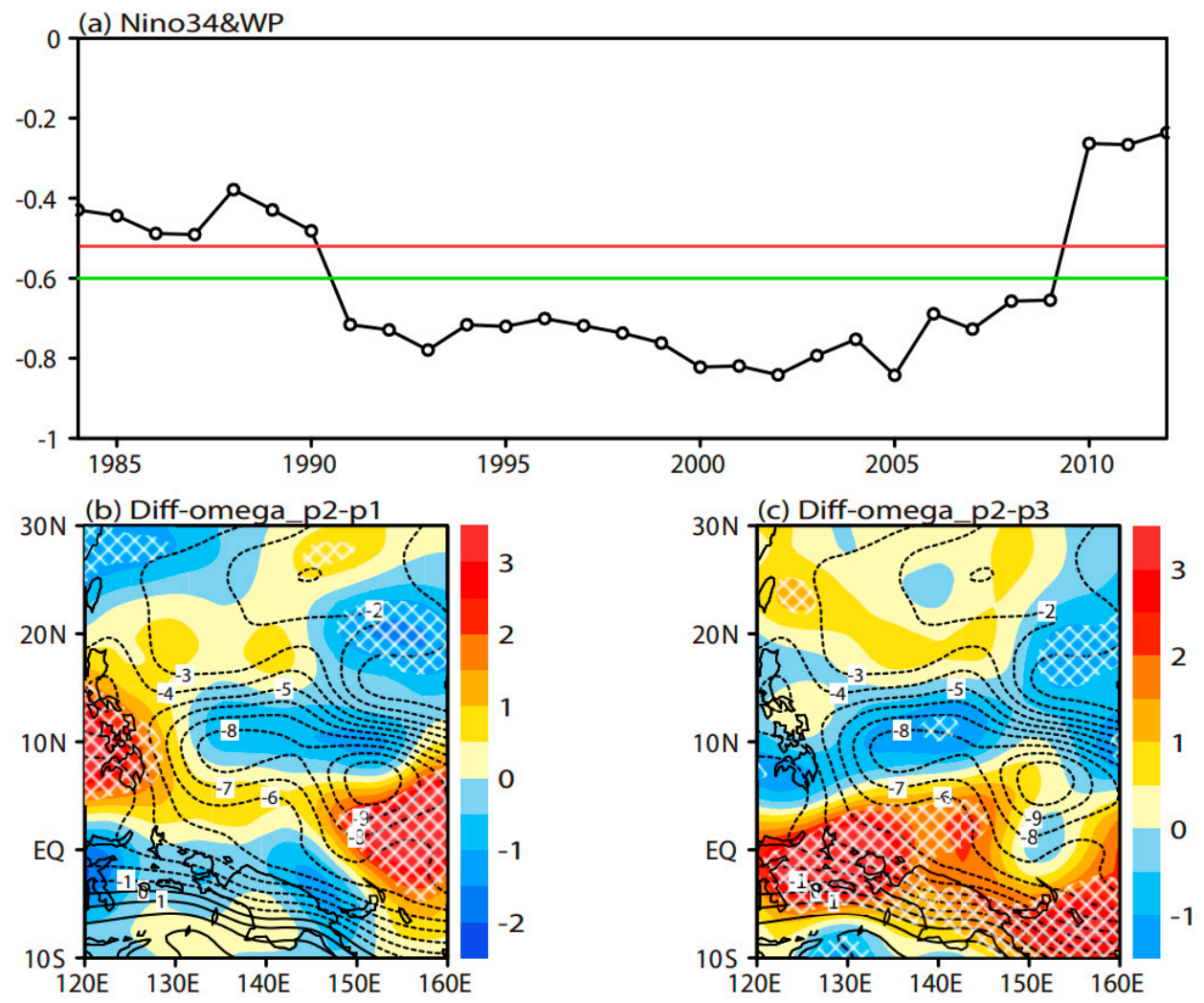

Figure 11. (a) 11-year sliding correlation of the Niño3.4 index and regionally averaged $\left(100^{\circ} \mathrm{E}-160^{\circ} \mathrm{E}\right.$, $10^{\circ} \mathrm{N}-20^{\circ} \mathrm{N}$ ) western Pacific region summer vertical velocity index (WPOI) at $500 \mathrm{hPa}$ during 1979-2017, where the red and green horizontal lines denote the $90 \%$ and $95 \%$ confidence levels of the correlation coefficient, respectively; (b) Difference in vertical velocity at $500 \mathrm{hPa}$ (unit P/s) between P2 and P1 (shaded region); (c) Difference in vertical velocity at $500 \mathrm{hPa}$ (unit P/s) between P3 and P1(shaded region). The contour represents the climatology of the vertical velocity at $500 \mathrm{hPa}$. The vertical velocity has been multiplied by 100 . The gridded regions indicate that the vertical velocity anomalous are positively and negatively significant at the $95 \%$ confidence level.

In summary, the results show that in P2, the central-eastern SST has a stronger relation with zonal circulation, but in P1 and P3, the central-eastern SST has a stronger relation with local meridional circulations and a weaker relation with zonal circulations. This indicates that the zonal circulation (Walker circulation) strengthens in P2 over the Pacific Ocean, which can strengthen the ascending motion over the western Pacific, thus, inducing the SHMC to strengthen and moving northward, resulting in a significantly stronger relationship with the NHMC.

\section{Conclusions and Discussion}

Using the NCEP/NCAR reanalysis data, we investigate the meridional circulations in Northern and Southern Hemispheres over western Pacific Ocean. The meridional circulation is mainly composed of two systems, i.e., the western North Pacific monsoon superimposed on local Hadley circulation in the $\mathrm{NH}$ and the local Hadley circulation in the SH. Previous studies have often researched this local meridional circulation as a whole system. In climatology, the NHMC and SHMC also show an integral consistent feature. However, these two meridional circulations do not have a positive change relationship but a significantly negative relationship. Moreover, this negative correlation is unstable, and experienced an interdecadal change.

Through the analysis of the meridional wind field at lower and upper levels, we found that the SHMC moves northward during P2, which builds a close relationship with the NHMC. In P1 and $\mathrm{P} 3$, the location of the SHMC is to the south and has a weak linkage with the NHMC. The possible 
mechanisms are as follows (Figure 12): In P2, the central-eastern SST has a stronger relation with zonal circulation, but in P1 and P3, the central-eastern SST has a stronger relation with local meridional circulation and a weaker relation with zonal circulation. This indicates that the zonal Walker circulation strengthens in P2, which strengthens ascending motion over the western Pacific Ocean, thus, inducing the SHMC to strengthen and move northward, resulting in a significantly stronger relationship with the NHMC. Therefore, the NHMC and SHMC have a significantly negative correlation during 1989-2003 (P2). Thus, in future research, because of the complexity of the local meridional circulation over the western Pacific, we need to divide the local meridional circulation into north and south branches.

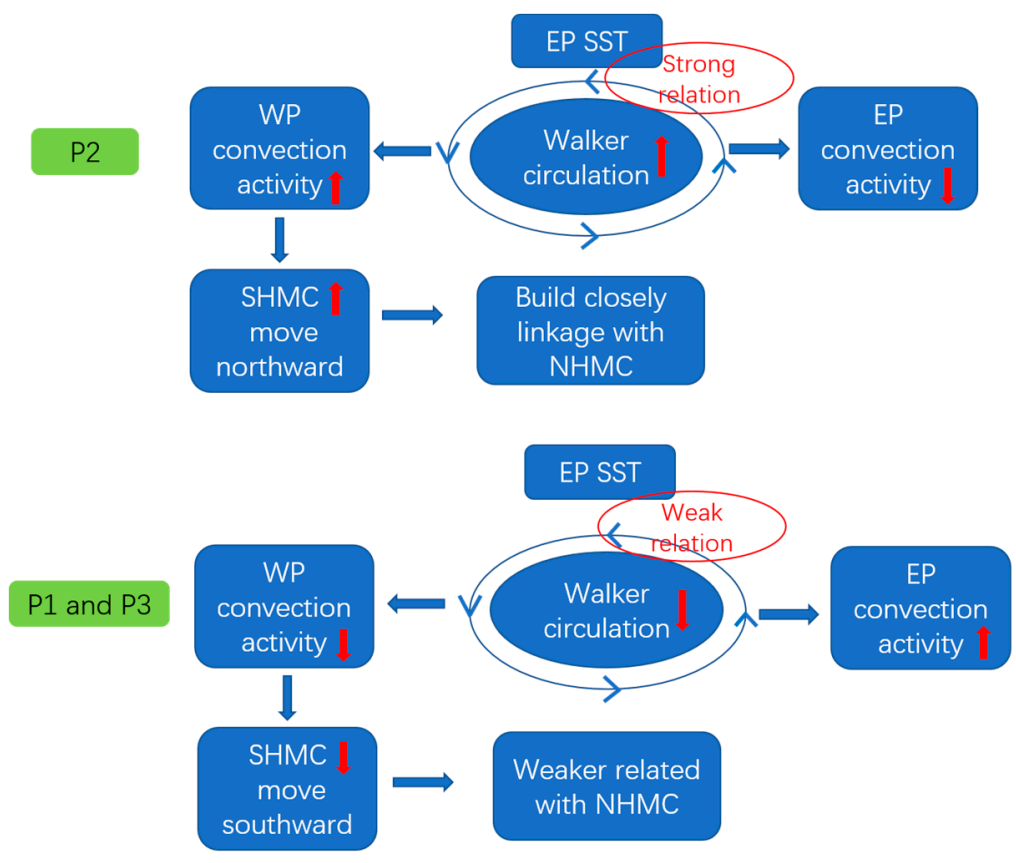

Figure 12. The schematic diagram of the possible mechanisms. The red arrow up indicates the system strengthens, the red arrow down indicates the system weakens.

The impact of the ENSO on atmospheric circulations is not stationary, which can be modulated by the Pacific decadal oscillation (PDO), and so on [39-45]. For example, the high-latitude PDO can, through low-latitude tropical Pacific SST, influence the Asian climate [44]. The ENSO pattern tends to be more stable and stronger during the positive phase of the PDO [40]. The strength and duration of the anomalous Walker circulation associated with El Niño or La Niña are distinct under the different phases of PDO [45]. In this work, the relationship between NHMCI and SHMCI has experienced an interdecadal change, which is modulated by the ENSO. The PDO, as the most remarkable pattern of decadal SST variability in the North Pacific, may, through ENSO, modulate the relationship between these two meridional circulations. In this article, we mainly focus on the interdecadal change of the linkage between NHMCI and SHMCI and found it may be influenced by the tropical Pacific SST through the ascending motion over the western Pacific Ocean. However, why the central-eastern SST has a stronger relation with zonal circulation in P2 and local meridional circulations in P1 and P3, and what causes this interdecadal change point still needs further study in future works by using numerical experiments.

In addition, the NHMC and SHMC also have a close relationship with Asian-Pacific monsoon summer precipitation. Figure 13 shows a significant tripole precipitation pattern correlated with these two meridional circulation indices in P2. However, the related precipitation patterns are different in P1 and P3, even with no significant signals of the NHMCI. The reason that precipitation shows a consistent tripole pattern of the NHMCI and SHMCI in P2, but the precipitation patterns are inconsistent, 
even with no signals in P1 and P3, will be discussed in our next study. Additionally, the dynamic numerical test is also investigated in the next research.
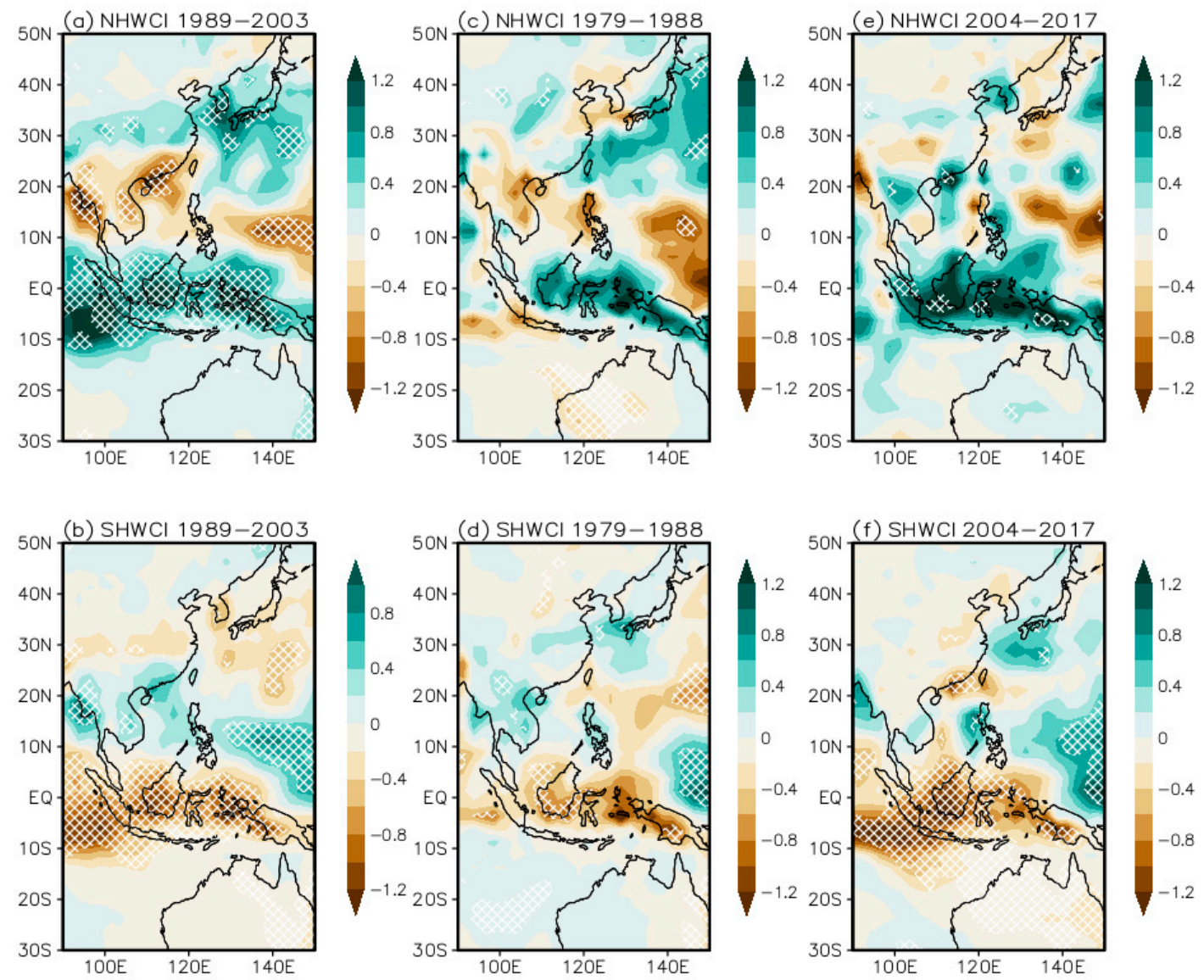

Figure 13. Linear regression maps of the NHMCI and SHMCI with the summer precipitation field during (a,b) 1989-2004; (c,d) 1979-1988; and (e,f) 2004-2017 (unit mm/day). The gridded regions represent the correlations that are positively and negatively significant at the $95 \%$ confidence level.

Author Contributions: Conceptualization, Y.G. and D.C.; methodology, D.C.; software, Y.G. and D.C.; validation, Y.G., D.C. and H.W.; formal analysis, Y.G. and D.C.; investigation, Y.G.; resources, D.C.; data curation, D.C.; writing-original draft preparation, Y.G.; writing—review and editing, Y.G.; visualization, D.C.; supervision, H.W.; project administration, Y.G.; funding acquisition, Y.G. All authors have read and agreed to the published version of the manuscript.

Funding: This research was funded by the National Key Research and Development Program of China, grant number 2017YFC1502304, the National Natural Science Foundation of China, grants numbers 41421004, 41875110, 41705066, and 41505070, and the CAS-PKU Joint Research Program.

Acknowledgments: This research was supported by the National Key Research and Development Program of China (grant no. 2017YFC1502304), the National Natural Science Foundation of China (grants no. 41421004, 41875110, 41705066, and 41505070), and the CAS-PKU Joint Research Program.

Conflicts of Interest: The authors declare no conflict of interest.

\section{References}

1. Nitta, T. Convective activities in the tropical western Pacific and their impact on the Northern Hemisphere summer circulation. J. Meteor. Soc. Jpn. 1987, 64, 373-390. [CrossRef]

2. Wang, B.; Wu, R.; Lau, K.M. Interannual Variability of the Asian Summer Monsoon: Contrasts between the Indian and the Western North Pacific-East Asian Monsoons. J. Clim. 2001, 14, 4073-4090. [CrossRef]

3. Xue, F.; Dong, X.; Lin, R.P. Two anomalous convective systems in the tropical western Pacific and their influences on the East Asian summer monsoon. Atmos. Ocean. Sci. Lett. 2017, 10, 319-324. [CrossRef] 
4. Gao, Y.; Wang, H.; Chen, D. Precipitation anomalies in the Pan-Asian monsoon region during El Niño decaying summer 2016. Int. J. Climatol. 2018, 38, 3618-3632. [CrossRef]

5. McCreary, J.P.; Anderson, D.L.T. A simple model of El Niño and the southern oscillation. Mon. Weather Rev. 1984, 112, 934-946. [CrossRef]

6. Schopf, P.S.; Suarez, M.J. Vacillations in a coupled ocean-atmosphere model. J. Atmos. Sci. 1988, 45, 549-566. [CrossRef]

7. Zhang, R.; Huang, R. Dynamical roles of zonal wind stresses over the tropical Pacific on the occurring and vanishing of El Niño. Part I: Diagnostic and theoretical analyses. Chin. J. Atmos. Sci. 1998, 22, 587-599. (In Chinese)

8. Li, C.; Mu, M. El Niño occurrence and sub-surface ocean temperature anomalies in the Pacific warm pool. Chin. J. Atmos. Sci. 1999, 23, 513-521. (In Chinese) [CrossRef]

9. Chang, C.P.; Li, T. A theory for the tropical tropospheric biennial oscillation. J. Atmos. Sci. 2000, 57, $2209-2224$. [CrossRef]

10. Huang, R.; Sun, F. Impacts of the tropical western Pacific on the East Asian summer monsoon. J. Meteor. Soc. Jpn. 1992, 70, 243-256. [CrossRef]

11. Zhang, R.H.; Sumi, A.; Kimoto, M. Impact of El Niño on the East Asian monsoon: A diagnostic study of the 86/87 and 91/92 events. J. Meteor. Soc. Jpn. 1996, 74, 49-62. [CrossRef]

12. Lu, R.Y. Interannual variability of the summertime North Pacific subtropical high and its relation to atmospheric convection over the warm pool. J. Meteor. Soc. Jpn. 2001, 79, 771-783. [CrossRef]

13. Gao, Y.; Wang, H. Pan-Asian Monsoon and its definition, principal modes of precipitation, and variability features. Sci. China Earth Sci. 2012, 55, 1-9. [CrossRef]

14. Oh, H.; Ha, K.J. Thermodynamic characteristics and responses to ENSO of dominant intraseasonal modes in the East Asian summer monsoon. Clim. Dyn. 2015, 44, 1751-1766. [CrossRef]

15. Gao, Y. Shift of the principal mode of Pan-Asian monsoon summer precipitation in terms of spatial pattern. Atmos. Oceanic Sci. Lett. 2017, 10, 221-227. [CrossRef]

16. Chen, J.; Carlson, B.E.; Del Genio, A.D. Evidence for strengthening of the tropical general circulation in the 1990s. Science 2002, 295, 838-841. [CrossRef] [PubMed]

17. Sohn, B.; Park, S.C. Strengthened tropical circulations in past three decades inferred from water vapor transport. J. Geophys. Res. 2010, 115, D15112. [CrossRef]

18. Fu, Q.; Lin, P. Poleward shift of subtropical jets inferred from satellite-observed lower-stratospheric temperatures. J. Clim. 2011, 24, 5597-5603. [CrossRef]

19. Zhou, Y.; Xu, K.M.; Sud, Y.; Betts, A. Recent trends of the tropical hydrological cycle inferred from Global Precipitation Climatology Project and International Satellite Cloud Climatology Project data. J. Geophys. Res. 2011, 116, D09101. [CrossRef]

20. Nguyen, H.; Timbal, B.; Evans, A.; Lucas, C.; Smith, I. The Hadley circulation in reanalyses: Climatology, variability and change. J. Clim. 2013, 26, 3357-3376. [CrossRef]

21. Zhou, B.T.; Wang, H.J. Interannual and interdecadal variations of the Hadley Circulation and its connection with tropical sea surface temperature. Chin. J. Geophys. 2006, 49, 1271-1278. (In Chinese) [CrossRef]

22. Sun, B. Asymmetric variations in the tropical ascending branches of Hadley circulations and the associated mechanisms and effects. Adv. Atmos. Sci. 2018, 35, 317-333. [CrossRef]

23. Zhou, B.T.; Cui, X. Modeling the influence of spring Hadley circulation on the summer tropical cyclone frequency in the western North Pacific. Chin. J. Geophys. 2009, 52, 2958-2963. (In Chinese) [CrossRef]

24. Zhou, B.T.; Cui, X. Modeling the relationship between spring Hadley circulation and the summer precipitation in the Yangtze River Valley. Clim. Environ. Res. 2008, 13, 182-188. (In Chinese)

25. Chen, S.; Wei, K.; Chen, W.; Song, L. Regional changes in the annual mean Hadley circulation in recent decades. J. Geophys. Res. Atmos. 2014, 119, 7815-7832. [CrossRef]

26. Huang, R.P.; Chen, S.F.; Chen, W.; Hu, P.; Yu, B. Recent strengthening of the regional Hadley circulation over the western Pacific during boreal spring. Adv. Atmos. Sci. 2019, 36, 1251-1264. [CrossRef]

27. Ambrizzi, T.; Souza, E.B.; Pulwarty, R.S. The Hadley and Walker regional circulations and associated ENSO impacts on South American seasonal rainfall. In The Hadley Circulation: Present, Past, and Future; Diaz, H.F., Bradley, R.S., Eds.; Kluwer Academic: New York, NY, USA, 2005; pp. 203-235. 
28. Zhao, H.; Moore, G. Trends in the boreal summer regional Hadley and Walker circulations as expressed in precipitation records from Asia and Africa during the latter half of the 20th century. Int. J. Climatol. 2008, 28, 563-578. [CrossRef]

29. Zeng, G.; Wang, W.C.; Sun, Z.B.; Li, Z.X. Atmospheric circulation cells associated with anomalous East Asian winter monsoon. Adv. Atmos. Sci. 2011, 28, 913-926. [CrossRef]

30. Freitas, A.C.V.; Aímola, L.; Ambrizzi, T.; Oliveria, C.P. Changes in intensity of the regional Hadley cell in Indian Ocean and its impacts on surrounding regions. Meteorol. Atmos. Phys. 2017, 129, 1-18. [CrossRef]

31. Huang, R.; Chen, S.; Chen, W.; Hu, P. Interannual variability of regional Hadley circulation intensity over western Pacific during boreal winter and its climatic impact over Asia-Australia region. J. Geophys. Res. Atmos. 2018, 123, 344-366. [CrossRef]

32. Li, Y.P.; He, J.H. Contrast expermiments on the effect of the $\mathrm{SH}$ cold air activity on the SH summer monsoon. J. Nanjing Inst. Meteorol. 1990, 13, 32-39. (In Chinese)

33. Zhu, Y. Variations of the summer Somali and Australia cross-equatorial flows and the implications for the Asian summer monsoon. Adv. Atmos. Sci. 2012, 29, 509-518. [CrossRef]

34. Adler, R.F.; Huffman, G.J.; Chang, A.; Ferraro, R.; Xie, P.P.; Janowiak, J.; Rudolf, B.; Schneider, U.; Curtis, S.; Bolvin, D. The version 2 global precipitation climatology project (GPCP) monthly precipitation analysis (1979-present). J. Hydrometeorol. 2003, 4, 1147-1167. [CrossRef]

35. Kanamitsu, M.; Ebisuzaki, W.; Woollen, J.; Yang, S.K.; Hnilo, J.J.; Fiorino, M.; Potter, G.L. NCEP-DOE AMIP-II Reanalysis (R-2). Bull. Amer. Meteorol. Soc. 2002, 83, 1631-1643. [CrossRef]

36. Kalnay, E.; Kanamitsu, M.; Kistler, R.; Collins, W.; Deaven, D.; Gandin, L.; Iredell, M.; Saha, S.; White, G.; Woollen, J.; et al. The NCEP/NCAR 40-Year reanalysis project. Bull. Amer. Meteor. Soc. 1995, 77, 437-472. [CrossRef]

37. Dee, D.P.; Uppala, S.M.; Simmons, A.J.; Berrisford, P.; Poli, P.; Kobayashi, S.; Andrae, U.; Balmaseda, M.A.; Balsamo, G.; Bauer, P.; et al. The ERA-Interim reanalysis: Configuration and performance of the data assimilation system. Q. J. Roy. Meteor. Soc. 2011, 137, 553-597. [CrossRef]

38. Smith, T.M.; Reynolds, R.W.; Peterson, T.C.; Lawrimore, J. Improvements to NOAA's historical merged land-ocean surface temperature analysis (1880-2006). J. Clim. 2008, 21, 2283-2296. [CrossRef]

39. Mantua, N.J.; Hare, S.R.; Zhang, Y.; Wallace, J.M.; Francis, R.C. A Pacific interdecadal climate oscillation with impacts on salmon production. Bull. Amer. Meteor. Soc. 1997, 78, 1069-1079. [CrossRef]

40. Gershunov, A.; Barett, T.P. Interdecadal modulation of ENSO teleconnections. Bull. Amer. Meteor. Soc. 1998, 79, 2715-2725. [CrossRef]

41. Mantua, N.J.; Hare, S.R. The Pacific decadal oscillation. J. Oceanogr. 2002, 58, 35-44. [CrossRef]

42. Wang, L.; Chen, W.; Huang, R.H. Interdecadal modulation of PDO on the impact of ENSO on the East Asian winter monsoon. Geophys. Res. Lett. 2008, 35, L20702. [CrossRef]

43. Yoon, J.; Yeh, S.W. Influence of the Pacific decadal oscillation on the relationship between El Niño and the northeast Asian summer monsoon. J. Clim. 2010, 23, 4525-4537. [CrossRef]

44. Feng, J.; Wang, L.; Chen, W. How Does the East Asian Summer Monsoon Behave in the Decaying Phase of El Niño during Different PDO Phases? J. Clim. 2014, 27, 2682-2698. [CrossRef]

45. Xue, X.; Chen, W.; Chen, S.; Feng, J. PDO modulation of the ENSO impact on the summer South Asian high. Clim. Dyn. 2018, 50, 1393-1411. [CrossRef]

Publisher's Note: MDPI stays neutral with regard to jurisdictional claims in published maps and institutional affiliations.

(C) 2020 by the authors. Licensee MDPI, Basel, Switzerland. This article is an open access article distributed under the terms and conditions of the Creative Commons Attribution (CC BY) license (http://creativecommons.org/licenses/by/4.0/). 